\title{
PENGEMBANGAN APLIKASI UNTUK MEMBANTU ANALISIS DATA SURVEY TENTANG PENTINGNYA PROGRAM PELATIHAN BIDANG TIK BAGI GURU BERBASIS “USER NEEDS ASSESMENT “
}

\author{
Agus Aan Jiwa Permana \\ Program Studi Manajemen Informatika, Fakultas Teknik dan Kejuruan \\ Universitas Pendidikan Ganesha, Singaraja Bali \\ agus.aan@undiksha.ac.id
}

\begin{abstract}
Information and Communication Technology (ICT) in general are all technologies related to the collection, collection, processing, storage, dissemination, and presentation of information widely applied in all fields, one of them in education. Teachers are professional educators who have an important role and role in the intellectual life of the nation. Regulation of the Minister of National Education No. 16 of 2007 dated May 4, 2007 on the standard of academic qualification and competence of teachers, especially on the Competency Standards of Elementary Teachers who in Pedagodic Competence is utilizing ICT for learning purposes and on Professional Competence is utilizing ICT to communicate and develop themselves. But in fact many teachers in Sukasada district, Buleleng who still do not understand the use of technology. Based on the description above the information system is needed survey through questionnaire related to the extent of the teacher skills in the field of ICT. In the analytical process an application is needed to help provide recommendations on the need for ICT training for teachers in schools.
\end{abstract}

Keywords : Information and Communication Technology Training, Teacher Competency Standards, Pedagogic Competencies, Questionnaire Analysis, Skills Survey

\begin{abstract}
ABSTRAK
Teknologi Informasi dan Komunikasi (TIK) secara umum adalah semua teknologi yang berhubungan dengan pengambilan, pengumpulan, pengolahan, penyim-panan, penyebaran, dan penyajian informasi yang banyak diterapkan di segala bidang, salah satunya di bidang pendidikan. Guru adalah pendidik professional yang mempunyai tugas dan peran penting dalam mencerdaskan kehidupan bangsa. Peraturan Menteri Pendidikan Nasional Nomor 16 Tahun 2007 tanggal 4 Mei 2007 tentang standar kualifikasi akademik dan kompetensi Guru, khususnya pada Standar Kompetensi Guru SD yang pada Kompetensi Pedagodik adalah me-manfaatkan TIK untuk kepentingan pembelajaran dan pada Kompetensi Profesional adalah memanfaatkan TIK untuk berkomunikasi dan mengembangkan diri. Namun kenyataannya banyak guru di kecamatan Sukasada, Buleleng yang masih belum memahami penggunaan teknologi. Berdasarkan uraian diatas sistem informasi sangat diperlukan survey melalui kuisioner terkait sejauh mana keterampilan guru di bidang TIK. Dalam proses analisi diperlukan sebuah aplikasi untuk membantu memberikan rekomendasi tentang perlunya diadakan pelatihan TIK untuk guru di sekolah.
\end{abstract}

Kata kunci: Pelatihan Teknologi Informasi dan Komunikasi, Standar Kompetensi Guru, Kompetensi Pedagodik, Analisis Kuisioner, Survey Keterampilan 


\section{PENDAHULUAN}

Teknologi Informasi dan Komunikasi (TIK/ICT) merupakan bagian dari ilmu pengetahuan dan teknologi yang secara umum adalah semua teknologi yang berhubungan dengan pengambilan, pengumpulan, pengolahan, penyimpanan, penyebaran, dan penyajian informasi. Saat ini perkembangan teknologi informasi khusus di Indonesia semakin berkembang. Sehingga dengan adanya TIK dapat memudahkan kita untuk belajar dan mendapatkan informa-si yang dibutuhkan dari mana saja, kapan saja, dan dari siapa saja. Dalam dunia pendidikan perkembangan teknologi informasi mulai dirasa mempunyai dampak yang positif karena dengan berkembangnya teknologi informasi dunia pendidikan mulai memperlihatkan perubahan yang cukup signifikan. Banyak hal yang dirasakan berubah dibandingkan dengan sebelumnya. Saat sekarang ini jarak dan waktu bukan lagi masalah yang berarti untuk mendapatkan ilmu karena berbagai aplikasi tercipta untuk memfasilitasinya.

Kemajuan perkembangan teknologi informasi berpengaruh terhadap dunia pendidikan yaitu mengenai cara pembelajaran yang berbasis e-learning atau juga cara pembelajaran distance learning. Pembelajaran e-learning sudah banyak diterapkan dalam perguruan-perguruan tinggi di Indonesia, baik itu perguruan tinggi negeri maupun swasta. Cara pembelajaran elearning ini juga diharapkan bisa diterapkan dalam proses belajar mengajar di sekolah, baik dari tingkat Sekolah Dasar (SD) tingkat Sekolah Menengah Atas (SMA).

Guru adalah pendidik professional yang mempunyai tugas dan peran penting dalam mencerdaskan kehidupan bangsa. Guru yang professional diharapkan mampu berpartisipasi dalam pembangunan nasional. Selain itu agar fungsi dan tugas yang melekat pada jabatan fungsional guru dilaksanakan sesuai dengan peraturan yang berlaku, maka diperlukan kompetensi atau seperangkat pengetahuan, keterampilan, dan perilaku yang harus dimiliki, dihayati, dikuasai, dan diaktualisasikan oleh guru khususnya dalam bidang komputer dalam melaksanakan tugas keprofesionalannya, melihat kepada Peraturan Menteri Pendidikan Nasional Nomor 16 Tahun 2007 Tanggal 4 Mei 2007 tentang Standar Kualifikasi Akademik dan Kompetensi Guru dan khususnya pada Standar Kompetensi Guru Kelas SD/MI yang pada Kompetensi Pedagodik dengan Kompetensi
Inti Guru Memanfaatkan teknologi informasi dan komunikasi untuk kepentingan pembelajaran dan pada Kompetensi Profesional dengan Kompetensi Inti Guru adalah Memanfaatkan teknologi informasi dan komunikasi untuk berkomunikasi dan mengembangkan diri.

Berdasarkan observasi pada kenyataannya masih banyak guru khususnya guru SD Negeri kecamatan Sukasada, Kabupaten Buleleng yang belum memahami teknologi informasi khususnya komputer, jangankan untuk membuka internet ataupun microsoft office mematikan dan menghidupkan komputer saja, beberapa guru belum bisa walaupun sekolah sudah memiliki komputer. Ada juga beberapa guru yang bisa mengoperasikan atau menggunakan microsoft word namun hanya sebatas bisa mengetik tanpa mengetahui cara untuk mengatur kertas, dan margin. Maka berdasarkan uraian tersebut diatas sistem informasi sangat diperlukan untuk mengetahui sejauh mana keterampilan guru menggunakan komputer sehingga penulis perlu melakukan penelitian lebih lanjut.

\section{TINJAUAN PUSTAKA}

\section{Pengertian Sistem Secara Umum}

Suatu sistem dapat terdiri dari beberapa subsistem atau sistem-sistem bagian. Komponen-komponen atau subsitem dalam suatu sistem tidak dapat berdiri lepas sendiri-sendiri. Komponen-komponen dan subsistem saling berinteraksi dan saling berhubungan membentuk satu kesatuan sehingga tujuan atau sasaran dapat tercapai. Sistem berasal dari bahasa Latin ("systema") dan bahasa Yunani ("susteme") adalah sekumpulan unser/elemen yang saling berkaitan dan saling mempengaruhi dalam melakukan kegiatan bersama untuk mencapai suatu tujuan. Menurut Sutarman (2009:5), sistem adalah kumpulan elemen yang saling berhubungan dan saling berinteraksi dalam satu kesatuan untuk menjalankan suatu proses pencapaian suatu tujuan utama. Menurut Jogiyanto (2009:34), sistem dapat didefinisikan dengan pendekatan prosedur dan dengan pendekatan komponen.

Menurut Jimmy L.Goal (2008:9), sistem adalah hubungan satu unit dengan unit-unit lainnya yang saling berhubungan satu sama lainnya dan yang tidak dapat dipisahkan serta menuju satu kesatuan dalam rangka mencapai tujuan yang telah ditetapkan. Apabila suatu unit macet atau terganggu, unit lainnya pun akan terganggu untuk 
mencapai tujuan yang telah ditetapkan tersebut. Menurut L. ACKOF, Sistem adalah setiap kesatuan secara konseptual atau fisik yang terdiri dari bagian-bagian dalam keadaan saling tergantung satu sama lainnya. Secara sederhana, suatu sistem dapat diarikan sebagaisuatu kumpulan atau himpunan dari unsur, komponen, atau variabel yang teroganisir, saling berinteraksi, saling tergantung satu sama lain, dan terpadu.

Menurut Mulyanto (2009:2), suatu sistem mempunyai karakteristik yaitu komponen sistem (component), batas sistem (boundry), lingkungan luar sistem (environment), penghubungan (interface), masukan (input) pengolahan (process), keluaran (output) dan sasaran (objective) atau tujuan (goal). pengolahan (process), keluaran (output) dan sasaran (objective) atau tujuan (goal). Sebuah sistem menurut (business dictionary, 2016) :

1. A set of detailed methods, procedures and routines created to carry out a specific activity, perform a duty, or solve a problem.

2. An organized, purposeful structure that consists of interrelated and interdependent elements (components, entities, factors, members, parts etc.). These elements continually influence one another (directly or indirectly) to maintain their activity and the existence of the system, in order to achieve the goal of the system. All systems have (a) inputs, outputs and feedback mechanisms, (b) maintain an internal steady state (called homeostasis) despite a changing external environment, (c) display properties that are different than the whole (called emergent properties) but are not possessed by any of the individual elements, and (d) have boundaries that are usually defined by the system observer.

\section{Pengertian Informasi}

Telah diketahui bahwa informasi merupakan hal yang sangat penting bagi manajemen dalam pengambilan keputusan. Beberapa ahli mendefinisikan informasi sebagai berikut :

Menurut Agus Mulyanto (2009 : 12), Informasi adalah data yang diolah menjadi bentuk yang lebih berguna dan lebih berarti bagi yang menerimanya, sedangkan data merupakan sumber informasi yang menggambarkan suatu kejadian yang nyata.

Menurut Jimmy L.Goal (2008 :8), Informasi adalah data yang telah diproses atau diolah ke dalam bentuk yang berarti untuk penerimanya dan merupakan nilai yang sesungguhnya atau dipahami dalam tindakan atau keputusan yang sekarang atau nantinya. Menurut Jogiyanto (2008:36), Informasi adalah data yang diolah menjadi bentuk yang berguna bagi para pemakainya.

\section{TIK Bagi Guru}

Dalam perkembangan dunia pendidikan diperlukan sebuah fasilitas penunjang untuk proses pembelajaran. Terdapat beberapa penjelasan terkait dengan TIK/ICT dengan profesi seorang guru khususnya sekolah dasar. Saat perangkat ICT masuk ke dalam sekolah menurut (Eady \& Lockyer, 2013) bahwa :

Technological devices and networks have changed our schools and classrooms. In Australia, technological investments in schools have been made at the state/territory level and at the national level through initiatives such as the Digital Education Revolution.

There now are computers and interactive whiteboards in schools, and schools are connected to each other and the world at higher speeds than ever before. Technology in schools has become mobile, with laptop computers, tablet devices and smartphones now part of the teaching and learning context.

ICT merupakan sebuah revolusi yang menurut (Schiller, 2000) bahwa The information revolution is reshaping schools. For the school principal, the use of word processing, desktop publishing, database and spreadsheet applications have become commonplace. With only a desktop or laptop computer and a modem, school leaders can use the Internet to search the World Wide Web, access list servers and newsgroups, and contact colleagues by e-mail. Schools are now under increasing pressure to meet the needs and expectations of a generation accustomed to computers. The challenges for principals are huge.

Penggunaan ICT untuk para guru dipandang sebuah tantangan besar. The emerging electronic technologies pose an enormous challenge to teachers because their use requires considerable shifts in their 
pre-existing knowledge, skills, and behaviors. One of the unique aspects of computers as an educational innovation is that their use demands many new skills and competencies and embraces changes to educational ideologies (Schiller, 2000).

\section{Fasilitas Sekolah}

Dengan fasilitas yang baik, sekolah ini diharapkan bisa memiliki siswa berprestasi, berprestasi mengajar, dan unggul dan berprestasi di sekolah. Tapi sayang, hal itu tidak sama di setiap sekolah. Bila dilihat dari sekolah di kota, rata-rata fasilitas pendukung di sekolah yang ada, meski jumlahnya bisa bertambah lagi. Fasilitas pendukung bisa berupa aktivitas indoor, lapangan, sarana belajar seperti bangku, kursi, meja, alat tulis kantor (ATK), barang electronik, dan peralatan olahraga.

Hal ini tentunya tidak luput dari perhatian pemerintah daerah ke sekolah-sekolah di sana. Tidak semua pemimpin mengalokasikan lebih banyak dana untuk pendidikan, lebih baik mengalokasikan dana untuk hal lain yang sepertinya dianggap penting. Tapi sekolah adalah tempat bagi orang untuk belajar dan mengajar, mendapatkan ilmu yang akan bermanfaat bagi bangsa. Begitu penting bagi para pendukung keuangan, baik pemerintah pusat maupun daerah untuk menyediakan fasilitas yang diperlukan bagi sekolah. Seperti halnya dewan di Kabupaten Badung yang mengusulkan untuk memberikan laptop ke sekolah dasar secara bersamaan (Bali Post, 26 Agustus 2016). Hal Ini akan sangat mendukung pembelajaran dengan dukungan fasilitas lab dan akses internet akan dapat meningkatkan daya dukung sekolah untuk lebih berprestasi dai bawah Kemendikbud.

Faktanya di semua sekolah memiliki fasilitas laptop atau komputer untuk mengurus data administrasi pendidikan dan kemungkinan memiliki fasilitas printer dan internet juga. Sehingga sebenarnya sangat penting bagi seorang guru memiliki pengetahuan dasar terkait ICT.

\section{a. Pembuatan Kuisioner Survey}

Adapun hal yang mendasari pembuatan angket survey dalam penelitian ini adalah :

1. Peraturan Menteri Pendidikan Nasional Nomor 16 Tahun 2007 Tanggal 4 Mei 2007 tentang Standar Kualifikasi Akademik Dan Kompetensi Guru dan khususnya pada Standar Kompetensi
Guru Kelas SD/MI yang pada Kompetensi Pedagodik dengan Kompetensi Inti Guru Memanfaatkan teknologi informasi dan komunikasi.

2. Artikel yang ditulis oleh Andayani, S., Hernawati, K., dan Setyaningrum, W., (2016) Tentang Upaya Meningkatkan Profesionalisme Guru-Guru Sekolah Dasar di Daerah Istimewa Yogyakarta melalui Pelatihan Komputer Berbasis User Needs Assesment.

Tabel 1. Indikator Kuisioner

\begin{tabular}{|r|l|}
\hline No & \multicolumn{1}{|c|}{ Indikator } \\
\hline 1 & $\begin{array}{l}\text { Guru perlu memiliki kemampuan } \\
\text { untuk mengoperasikan komputer }\end{array}$ \\
\hline 2 & $\begin{array}{l}\text { Guru perlu mengenal aplikasi } \\
\text { komputer seperti word, excel, power } \\
\text { point, browser. }\end{array}$ \\
\hline 3 & $\begin{array}{l}\text { Guru mampu mengakses internet } \\
\text { melalui komputer yang sudah } \\
\text { terkoneksi internet }\end{array}$ \\
\hline 4 & $\begin{array}{l}\text { Guru harus memiliki email dan } \\
\text { mampu menggunakannya }\end{array}$ \\
\hline 5 & $\begin{array}{l}\text { Guru mampu mengajar } \\
\text { menggunakan media komputer }\end{array}$ \\
\hline 6 & $\begin{array}{l}\text { Guru mampu menggunakan aplikasi } \\
\text { pengolah kata seperti word }\end{array}$ \\
\hline 7 & $\begin{array}{l}\text { Guru mampu menggunakan aplikasi } \\
\text { pengolah angka seperti excel atau } \\
\text { sejenisnya }\end{array}$ \\
\hline 8 & $\begin{array}{l}\text { Guru mampu menggunakan aplikasi } \\
\text { presentasi seperti power point atau } \\
\text { sejenisnya }\end{array}$ \\
\hline 9 & $\begin{array}{l}\text { Guru mampu menggunakan web } \\
\text { browser seperti internet explore, } \\
\text { mozilla, chrome, opera atau } \\
\text { sejenisnya }\end{array}$ \\
\hline
\end{tabular}

Berdasarkan kedua sumber ini maka diperoleh sebuah angket survey yang memiliki indikator (9 buah) yang sudah dibuat sesuai dengan kebutuhan guru SD dengan penilaian skala Likert untuk mengukur kesetujuan dan ketidaksetujuan seseorang terhadap sesuatu objek seperti Tabel 1 dengan setiap indikator mengandung nilai seperti Tabel 2. Prosentase kelayakan dapat dirumuskan seperti persamaan 1 .

\section{(Jumlah skor per indikator/jumlah skor yang diharapkan (skor maks * jumlah responden)) $x$ 100\%}


Tabel 2. Rentangan Skor Per Indikator

\begin{tabular}{|l|c|}
\hline \multicolumn{1}{|c|}{ Keterangan Skor } & Nilai \\
\hline Sangat Setuju Sekali (SSS) & 5 \\
\hline Setuju Sekali (SS) & 4 \\
\hline Cukup Setuju (CS) & 3 \\
\hline Kurang Setuju (KS) & 2 \\
\hline Sangat Kurang Setuju (SKS) & 1 \\
\hline
\end{tabular}

Kemudian hasil perhitungan dengan persamaan 1 akan menghasilkan kategori kelayakan dalam bentuk persentase. Pembagian persentase kelayakan $100 \%$ dibagi rata menjadi lima kategori sesuai dengan jumlah skala likert (Arikunto, 2009: 44 Dalam IIkhsan, 2014) seperti Tabel 3.

Tabel 3.Prosentase Kelayakan

\begin{tabular}{|c|c|l|}
\hline No & Presentase (\%) & \multicolumn{1}{|c|}{ Kategori } \\
\hline 1 & $<21 \%$ & Sangat Tidak Layak \\
\hline 2 & $21 \%-40 \%$ & Tidak Layak \\
\hline 3 & $41 \%-60 \%$ & Cukup Layak \\
\hline 4 & $61 \%-80 \%$ & Layak \\
\hline 5 & $81 \%-100 \%$ & Sangat Layak \\
\hline
\end{tabular}

\section{METODELOGI PENELITIAN}

Dalam proses penelitian metode yang diterapkan adalah dengan melakukan observasi dengan melihat langsung keadaan di sekolah. Selanjutnya untuk melengkapi data dilakukan proses wawancara dengan kepala sekolah terkait dengan permasalah yang para guru hadapi dalam era teknologi.

Selain wawancara proses pengambilan data dilakukan dengan menggunakan kuisioner. Data yang diambil adalah berasal dari guru SD Negeri di Desa Panji, kecamatan Sukasada, Kabupaten Buleleng yang berjumlah 60 orang. Data yang diperoleh dengan menyebarkan angket kepada responden di enam sekolah yang terdapat disana. Responden mengisi angket, tim mengumpulkan angket dan memasukkan data yang diperoleh ke dalam sistem.

\section{HASIL DAN PEMBAHASAN}

Hasil implementasi dan pengujian sistem adalah seperti halaman login, halaman utama, skoring data rekap per sekolah, dan infomasi dan keputusan terkait dengan prosentase total setiap sekolah. Hak akses user adalah admin, operator, dan juga pihak berwenang yang memerlukan untuk analisis data seperti dinas dan institusi terkait. Halaman utama sistem seperti Gambar 1.

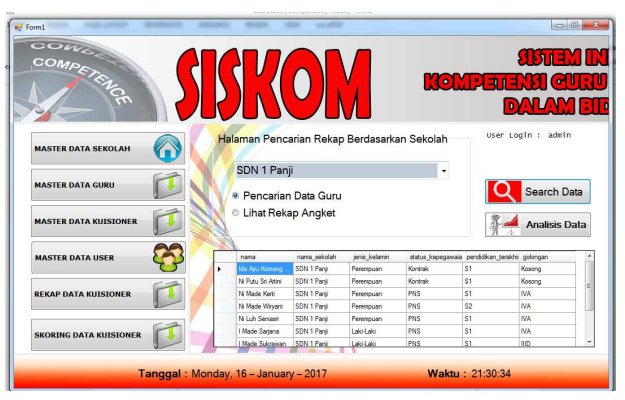

Gambar 1. Halaman Utama

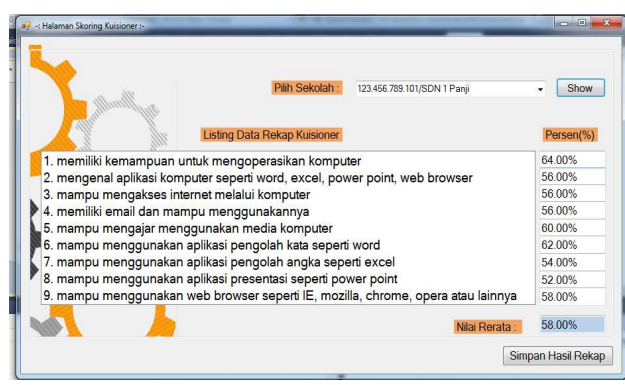

Gambar 2. Rekap Data Survey

Halaman utama digunakan untuk mengakses master data sistem dan merekap hasil survey seperti Gambar 2 dan melakukan analisis yang menghasilkan keputusan seperti Gambar 3. Setelah masa uji coba, terbukti sistem telah dapat membantu proses rekap kuisioner yang disebar ke sekolah-sekolah dan mengeluarkan hasil berupa rekomendasi yang mengindikasikan perlu untuk dilakukan pelatihan TIK atau tidak.

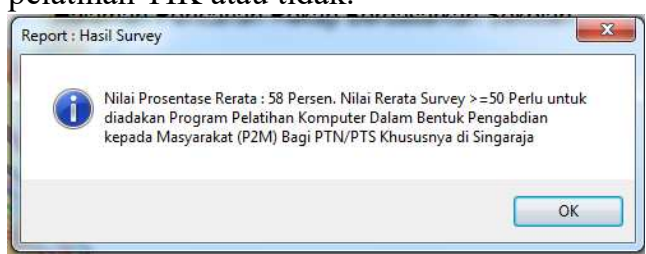

Gambar 3. Report Hasil Analisis

Apabila para guru di sekolah memerlukan pelatihan berdasarkan isi kuisioner, maka hasil kuisioner ini dapat digunakan sebagai pertimbangan untuk membuat proposal pengabdian pada masyarakat (P2M) untuk memperolah dana melalui DIKTI atau Institusi. Bahkan pelatihan dari dinas pendidikan atau kominfo di masing-masing wilayah dapat menggunakan data hasil survey untuk mengadakan pelatihan tentang TIK untuk meningkatkan keterampilan guru sehingga akan membantu proses pembelajaran maupun administrasi. Apabila 
kegiatan P2M dilakukan maka pada akhir kegiatan sudah semestinya melakukan pengukuran respon terhadap peserta pelatihan untuk mengetahui efektivitas dan efisiensi pelatihan (Sugihartini, dkk., 2017).

Dengan kalkulasi terhadap tanggapan responden diperoleh dari data survey menggunakan kuisioner selanjutnya sistem menghitung secara otomatis dan menyimpan hasil perhitungan survey per sekolah ke dalam basisdata. Sehingga diharapkan dapat diakses dan dilakukan perbandingan apabila suatu saat diperlukan oleh pihak terkait seperti dinas pendidikan dari pemerintah daerah, perguruan tinggi, atau institusi lainnya untuk memberikan pelatihan tentang TIK yang dapat meningkatkan kemampuan para guru di sekolah tersebut untuk menggunakan komputer, mengakses internet, menggunakan aplikasi, dan memanfaatkan TIK untuk membantu proses pembelajaran maupun administrasi. Dalam proses pengujian sistem, sampel Adapun alasan menyebarkan angket di sekolah SD karena berdasarkan observasi dan wawancara di lapangan yang menyatakan bahwa guru SD banyak yang belum paham untuk menggunakan teknologi komputer.

\section{SIMPULAN}

Sistem telah mampu untuk diimplementasikan dengan baik dan setelah proses uji coba sistem telah mampu membantu proses survey terkait keterampilan guru khusunya di lingkup sekolah dasar dalam bidang TIK. Hal tersebut dapat dilihat dari hasil angket yang diisi masing-masing guru yang kemudian diolah menghasilkan skor prosentasi total di suatu sekolah yang selanjutnya dapat digunakan sebagai pedoman untuk melakukan pengabdian pada masyarakat dalam bentuk pelatihan dan pendampingan bagi guru untuk meningkatkan kemampuan mereka di bidang TIK.

\section{DAFTAR PUSTAKA}

[1] Andayani, S., Hernawati, K., dan Setyaningrum, W., (2016) Upaya Meningkatkan Profesionalisme GuruGuru Sekolah Dasar di Daerah Istimewa Yogyakarta melalui Pelatihan Komputer Berbasis User Needs Assesment, http://eprints.uny.ac.id/43044/, diakses : 10 September 2016
[2] Koran Bali Post, Terbit 26 Agustus 2016

[3] Eady, M. J. \& Lockyer, L. 2013, 'Tools for learning: technology and teaching strategies', Learning to Teach in the Primary School, Queensland University of Technology, Australia. pp. 71

[4] Gaol, L, Jimmy. 2008. Sistem Informasi Manajemen Pemahaman dan Aplikasi.Jakarta : Penerbit PT Grasindo

[5] Jogiyanto, HM. (2009). Analisis dan Desain. Yogyakarta: Andi OFFSET

[6] Jogiyanto. 2008. Metodologi Penelitian Sistem Informasi. CV Andi Offset.Yogyakarta

[7] Mulyanto, Agus. (2009). Sistem Informasi Konsep dan Aplikasi. Pustaka Pelajar

[8] Peraturan Menteri Pendidikan Nasional Nomor 16 Tahun 2007 Tanggal 4 Mei 2007

[9] Schiller, J. 2000, Education: The Global Challenge, The Annual Conference of the Australi an Council for Educational Administra tion, September 9-12, 2000, Hobart, Tasman ia, Australia

[10] Sugihartini, N., Agustini, K., Pradnyana, D.A., 2017, Penerapan ELearning Di Smkn 2 Tabanan (Kajian Respon Pelatihan), Jurnal Widya Laksana, P-ISSN: 1410-4369 | E-ISSN: 2549-6859 Vol. 6, No. 1, Januari 2017

[11] Sutarman, 2009, Pengantar Teknologi Informasi, Bumi Aksara : Jakarta 